\title{
A CONTRIBUTION TO THE DEVELOPMENT OF THE
} FLAME-PHOTOMETRIC DETERMINATION OF SODIUM AND
POTASSIUM IN BLOOD SERUM
(FIRST COMMUNICATION)

\author{
by \\ J. SMIT AND C. T. J. ALKEMADE \\ Physical Laboratory of the University, Utrecht (Netherlands) \\ and \\ J. C. M. VERSCHURE \\ Biochemical Laboratory of the Medical Clinics of the University, \\ Utrecht (Netherlands)
}

\section{INTRODUCTION}

Determinations of sodium and potassium in blood serum and other fluids and tissues of the body are becoming more and more important in clinical investigation. Their value has been proved, for example, in studies of diabetic coma, uraemic coma, different kinds of shock, adrenal insufficiency and other complex endocrinological disorders.

However, the available chemical determinations, especially in the case of potassium, are lengthy, fairly complicated, and not altogether trustworthy. Therefore clinical investigation would greatly benefit by a simpler, more rapid and more accurate determination, requiring only a small quantity of mateiial.

In this regard a spectrochemical method, in which the emission spectrum of the atoms at high temperature is measured, would seem to be the most suitable. Flame photometry is such a method. Into a flame possessing the high temperature required (obtained by burning suitable gas mixtures) the solution containing sodium or potassium ions is introduced by means of a spray. The solvent is evaporated, the molecules dissociate and the atoms are excited to spectral emission. The intensity of the spectral lines emitted is measured with the aid of a photo-sensitive element after suitable selection by means of a spectrograph, a monochromator, a filter or combination of filters.

When properly carried out, this method meets all the requirements mentioned above. However, it is often difficult to obtain reproducible results as many empirical factors are involved in such a determination. Therefore the chief aim of this investigation is a further study of the flame-photometric determination of sodium and potassium and of the factors involved.

\section{APPARATUS}

In the Netherlands, flame spectrography for analytical purposes has been developed References $p .523$. 
by SCHUFFELEN ${ }^{1}$; flame photometry has been practised, among others, by Domingo BOON $^{3}$ and WILLEBRANDS, in the latter case applied to blood serum. Gas mixtures employed were: butane-air, coal gas-air, acetylene-air. The intensity of the emitted light has been measured with the aid of photographic plates, photo-cells and phototubes, in the latter case sometimes combined with electronic amplification. In photo-electric methods filters were used to separate the lines.

We chose an air-acetylene flame. The compressed air was simultaneously used to atomize the solution to be analyzed and to bring the haze into the flame. After separation by filters, the intensities of the yellow Na line $(5890-96 \AA)$ and the red $\mathrm{K}$ line $(7665-99 \AA)$ were measured by means of a vacuum phototube. By interrupting the light of the flame the photo-electric current could be amplified by an a.c. amplifier and measured by an a.c. galvanometer ${ }^{8,9}$.

\section{The Flame}

The flame has several advantages over the arc or the spark as an emission medium. Its emission is very constant and its spectrum relatively simple. However, as its temperature is relatively low, it can only be applied to elements with spectral lines of low excitation potentials (I to $3-4 \mathrm{eV}$ ).

WAIBEI $^{5}$ found air-acetylene to be the most favourable of several gas mixtures tested as regards the intensity quotient of spectral lines and background (mainly band spectra).

Our burner resembles that used by HEIERMaN ${ }^{6}$ and Vendrik ${ }^{7}$ when investigating alkali vapours in the acetylene flame. It has a cylindrical form and contains chambers from which the gases, after thorough mixing, flow out fairly rapidly through a number of small canals in the centre of the upper plate. Just above these canals the gas mixture is ignited. The lower plate is pressed against the wall of the box with springs to serve as a safety valve in case of explosion inside the burner. It is constructed of brass and needs no cooling.

TABLE I

QUANTITATIVE DATA REGARDING BURNER AND FLAME

\begin{tabular}{l|c}
\hline Burner: diameter & $40 \mathrm{~mm}$ \\
height & $45 \mathrm{~mm}$ \\
number of canals in upper plate & 60 \\
diameter of canals & $0.8 \mathrm{~mm}$ \\
Flame: & $3 \mathrm{~mm}$ \\
height of first zone of fire & $250 \mathrm{~mm}$ \\
diameter & $15 \mathrm{~mm}$ \\
air supply per minute & $181 \mathrm{at} 20^{\circ} \mathrm{C}$ I Atm. \\
acetylene supply per minute & $1.81 \mathrm{at} \mathrm{same}$ \\
temperature measured & $2400^{\circ} \mathrm{K}$. \\
estimated maximum content of & \\
Na atoms (when atomizing a & \\
solution of NaCl of I m.mol/1) & $3 \cdot 10^{13} / \mathrm{ml}$ \\
velocity (measured by photo- & \\
graphing flashes with a rotating & camera) \\
brightness (with above- & $16 \mathrm{~m} / \mathrm{sec}$ \\
\hline
\end{tabular}

For constant emission the supplies of acetylene and air should be constant. The gas supply is checked by a manometer which measures the difference in pressure between 
the ends of a capillary tube through which the gas current is conducted. For the air supply the manometer is filled with mercury, for the acetylene supply water is used. This current-manometer has the advantage over ordinary manometers that it is independent of possible changes in resistance which the gas current may meet within atomizer or burner.

The gas supplies are regulated by adjusting the valves attached to the cylinders. Thus adequate constancy is attained.

\section{The Spraty}

The spray (Fig. I) used was constructed as indicated by BooN ${ }^{8}$. It has the advantage that the solutions to be analyzed can be easily and rapidly changed. However, it is not very practicable for small samples, as only part of the aspirated solution is brought into the flame, while the rest remains on the bottom of the spray chamber. The quantity of liquid atomized per minute not only depends upon the air pressure, the diameter and the relative orientation of the capillary openings, but also on the viscosity and the surface tension of the aspirated solution.

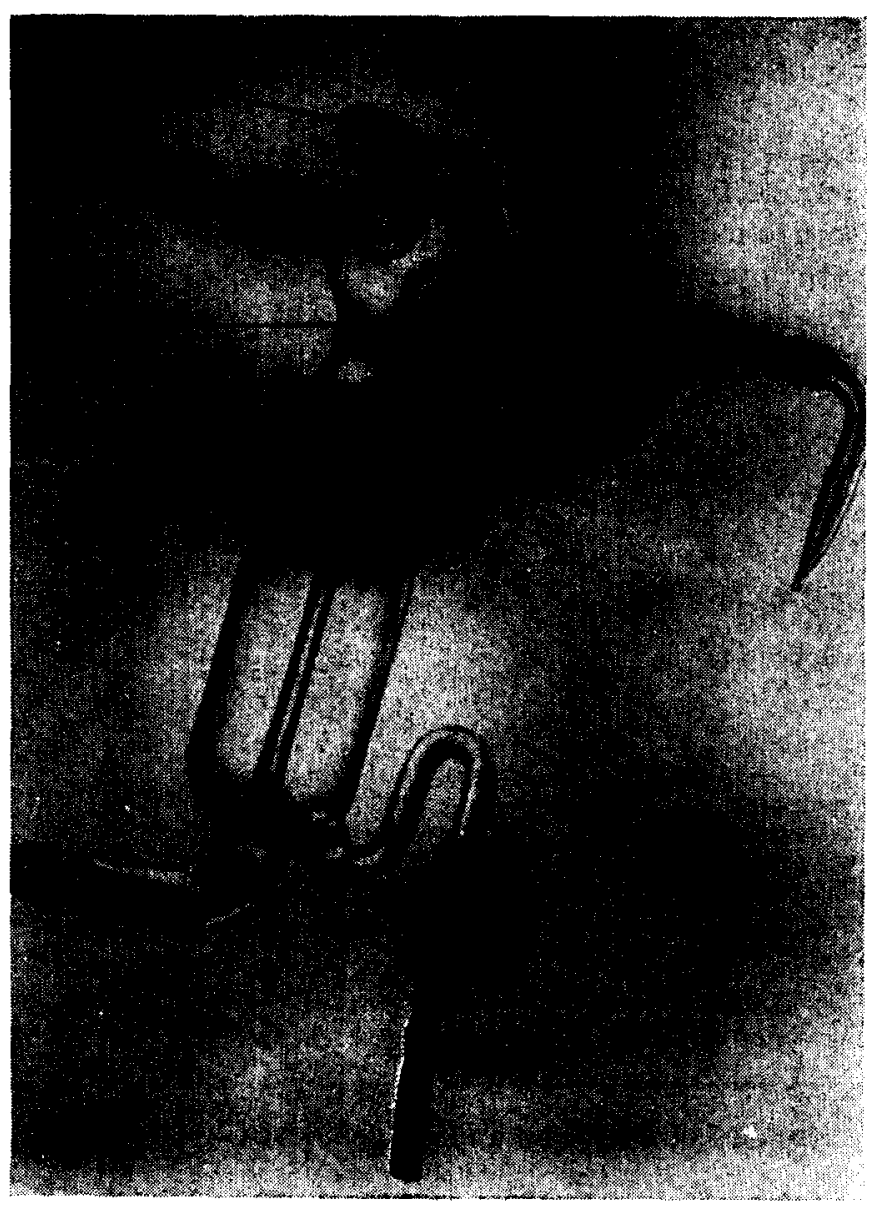

Fig. I. The spray. Compressed air introduced by $t$ atomizes the solution aspirated through $c$, the haze strikes bulb $b$ and leaves the spray via exit $e$. The remaining liquid is removed 
It is desirable to draw out the inlet of the aspirator tube into a narrow capillary to prevent blocking by solid particles which are inevitably present in the liquid and to prevent large drops, which would contaminate the next solution, from remaining at the entrance. The difference in height between the surface of the solution in its container and the exit of the aspirator tube should not be too large; the hydrostatic counter pressure may critically influence the speed of aspiration.

TABLE II

QUANTITATIVE DATA CONCERNING THE SPRAY

\begin{tabular}{|c|c|c|}
\hline & at $\mathrm{I} 8^{\circ} \mathrm{C}$ & at $40^{\circ} \mathrm{C}$ \\
\hline $\begin{array}{l}\text { Quantity aspirated per minute: } \\
\text { distilled water } \\
\text { trichloroacetic acid } 5 \% \\
\text { Percentage of above quantity remaining } \\
\text { in spray chamber: } \\
\text { distilled water } \\
\quad \text { trichloroacetic acid } 5 \% \\
\text { Aspiratory pressure }\end{array}$ & $\begin{array}{l}6.8 \mathrm{ml} \\
6.4 \mathrm{ml} \\
\\
95 \\
94.5 \\
2.6\end{array}$ & $\begin{array}{c}7.6 \mathrm{ml} \\
7.3 \mathrm{ml} \\
\\
97 \\
97\end{array}$ \\
\hline
\end{tabular}

\section{The measuring apparatus}

The optics consist of one lens of large aperture of unit magnification, focussing a well-defined part of the flame on the photosensitive layer of the photo tube.

The Na line (5890-96 $\AA$ ) and the $\mathrm{K}$ line $(7665-99 \AA)$ are selected by a combination of glass filters. These are mounted as a carrier and can easily be moved to a fixed position in front of the opening of the box containing the phototube.

Filters were preferred to a monochromator because they transmit more light and are much cheaper. The disadvantage of their lower selectivity, which is especially apparent in the determination of $K$ can be met satisfactorily, as will be discussed in $V, 2$. The background emission necessitates a correction in the determination of $\mathrm{K}$ in serum as the $K$ content of serum is fairly low.

To simplify the amplification in routine determinations in serum, the stronger $\mathrm{Na}$ line was weakened with a blue glass plate until the galvanometer deflection was about the same as for the weaker $\mathrm{K}$ line.

A Cs- $\mathrm{Cs}_{2} \mathrm{O}$ vacuum phototube was used, which is sensitive in the yellow and red regions of the spectrum. The photocurrent is amplified by an a.c. amplifier, as described by ${ }^{\prime}$ MILATz, ${ }^{8}$. The synchronously rotating disc, which generates the intermittent light required, is placed just before the flame, so that only the light of the flame is modulated and amplified, excluding the scattered light from the room.

The amplified a.c. output is measured by an a.c. galvanometer, the magnetic field of which is generated by an electro-magnet fed by an a.c. current of the same phase and trequency as the current to be measured. Thus complete insensitivity to stray light of different frequency is attained. It is also possible to adjust the a.c. galvanometer so that its sensitivity becomes independent of small variations of strength of the a.c. magnetic field ${ }^{10}$. Its zero point is independent of variations in the voltage supply. The a.c. galvanometer is coupled to the last tube of the a.c. amplifier by means of a condenser.

The apparatus described above has the advantage that, except for the burner, it 
may be constructed from existing standard accessories, which are commercially available. The design and the prototype of the burner are kept in the Physical Laboratory of the University at Utrecht.

TABLE III

QUANTITATIVE DATA CONCERNING THE MEASURING APPARATUS

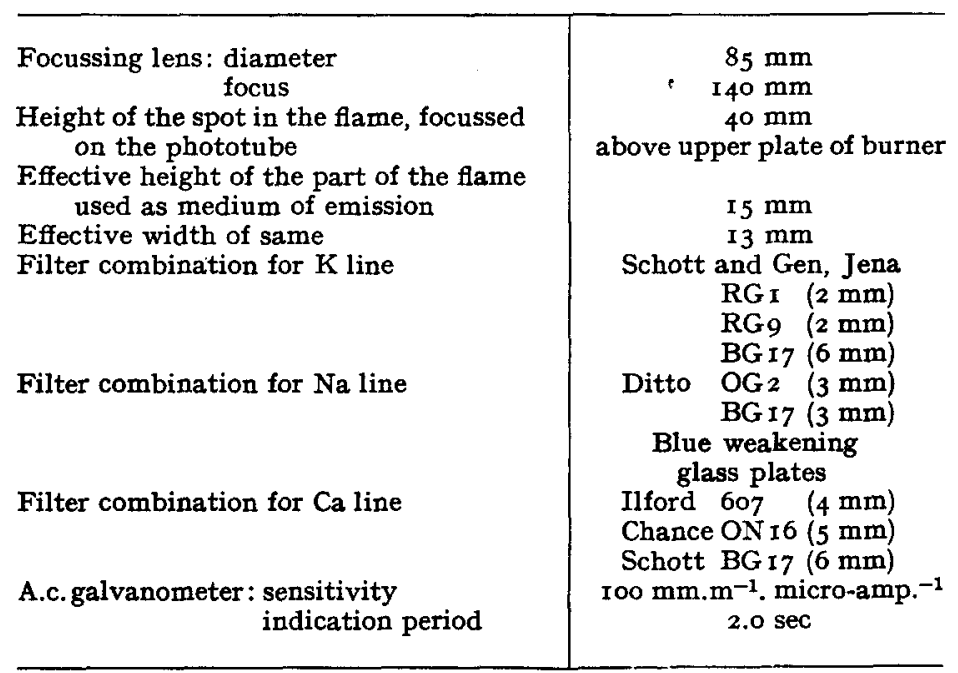

\section{PREPARATION OF MATERIALS BEFORE TESTING}

The serum to be investigated is diluted ten times with a $5 \%$ solution of trichloroacetic acid. The proteins, which are quantitatively precipitated, are removed by filtration and the clear filtrate can be used in the flame photometer. The relation between galvanometer deflection and alkali content is found by spraying a series of standard solutions containing $\mathrm{KCl}$ (0.38-r.I5 mmol. per liter) and $\mathrm{NaCl}(8.7-\mathrm{I} 6.5 \mathrm{mmol}$. per liter) in $5 \%$ trichloroacetic acid. These solutions are kept in pyrex flasks. Serum may also be preserved for several days if kept in the cold in pyrex or other hard glass containers. This glass must be used in all chemical manipulations. Before starting measurements standard and test solutions should have the same temperature (see VI, a).

\section{DISCUSSION}

a. Owing to its high viscosity the serum cannot be well atomized without dilution. Dilution with distilled water gives partial precipitation, mainly of $\gamma$ and $\beta$ globulins, which may cause obstruction of the aspirator tube. The degree of dilution with distilled water also proved to influence the product of speed and yield of atomization. (The speed of atomization is defined as $\mathrm{ml}$ solution aspirated per minute; the yield is defined as the percentage of the aspirated solution leaving the spray as a haze).

Furthermore, $\mathrm{K}$ and $\mathrm{Na}$ are partly absorbed by the proteins. Determinations, carried out on normal sera after dilution with distilled water, appeared to be too low (Na: $-20 \% ; \mathrm{K}:-30 \%$ ). Given quantities of $\mathrm{Na}$ and $\mathrm{K}$, added to sera of known composition, were also recovered with the same percentage loss. The absorption could be 
demonstrated by investigating the proteins, separated by ultra-filtration of the serum, after suitable treatment. They appeared to carry about ten percent of the total alkali content of the serum.

All these difficulties are evaded by deproteinization as described. As speed and yield of the atomization are influenced by the acid (Table IV), the same amount was added to the standard solutions.

b. The influence on the atomization of several organic solvents, added to the solution to be analyzed, was also investigated. To determine the relative galvanometer deflection, $2 \mathrm{mg} \mathrm{K}$ per Ioo $\mathrm{ml}$ were also added, as $\mathrm{KCl}$. Table IV lists the solvents with which an increased yield was obtained.

\section{TABLE IV}

INFLUENCE OF ORGANIC SOLVENTS ON THE ATOMIZATION

\begin{tabular}{l|c|c|c}
\hline \multicolumn{1}{c|}{ Solvent } & $\begin{array}{c}\text { Speed } \\
\mathrm{ml} / \mathrm{min}\end{array}$ & $\begin{array}{c}\text { Yield } \\
\mathrm{pCt}\end{array}$ & $\begin{array}{c}\text { Relative } \\
\text { deflection }\end{array}$ \\
\hline Distilled water & 3.5 & 5 & 100 \\
Trichloroacetic acid 5\% & 2.8 & 5.5 & 86 \\
isoButanol 10\% & 2.7 & 11 & 600 \\
isoPropanol 10\% & 2.7 & 8 & 390 \\
isoPropanol 25\% & 2.0 & 16 & 580 \\
isoButanol 20\% & & 33 & 830 \\
\hline \multicolumn{1}{c|}{+ acetone 20\% } & 2.15 & & \\
\hline
\end{tabular}

Allowing for the non-essential differences in speed, we see that an increase in yield is correlated with an increase in deflection. Several explanations arise for the nonlinearity of this relation. Firstly, the proportion of the drops, generated by the atomization, which actually reach the flame, may vary. Secondly, and more important in our opinion, is the mean diameter of the drops formed. Drops which are too large to be evaporated in time do not contribute to the emission. Thirdly, in some of the cases listed in Table IV a small increase of background emission was observed. Fourthly, as will be shown in $V, I$, the emission of $K$ is not necessarily directly proportional to the number of $\mathrm{K}$ atoms in the flame.

Qualitative relations were observed to exist between the yield and the surface tension of the solution. The surface tension partly determines the average diameter of the drops formed, thus influencing the yield. However, other factors must also determine the yield, for contrary to expectation the yield decreases with increasing temperature, when the surface tension decreases (II, 2). The dependence of the speed of atomization on temperature is largely due to the viscosity (II, 2).

The yield can be considerably increased by diminishing the speed of atomization. We have, however, worked under conditions in which the value of the product of speed and yield was optimal.

For routine determinations none of the organic solvents mentioned were used as yet besides trichloroacetic acid $5 \%$, as it was feared that complications might arise in practice owing to their volatility and to the restricted solubility of $\mathrm{NaCl}$ and $\mathrm{KCl}$ in some solvents.

c. The tenfold dilution of blood serum as chosen for routine analysis is optimal with 
respect to: the speed of atomization, the time required for a simultaneous determination of $\mathrm{Na}$ and $\mathrm{K}$, and the proportion between the weak $\mathrm{K}$ line and the fairly strong background emission in the region transmitted by the filters. With this dilution $0.5 \mathrm{ml}$ of serum suffices for a combined determination of $\mathrm{K}$ and $\mathrm{Na}$.

d. The standard solutions contain both $\mathrm{Na}$ and $\mathrm{K}$ in appropriate concentrations, as the $\mathrm{Na}$ content of the solution also proved to have an influence on the galvanometer deflection in the determination of $\mathrm{K}$.

The influence of calcium in the serum on the determination of $\mathrm{K}$ and $\mathrm{Na}$ is negligible (less than I \%).

e. The addition of trichloroacetic acid to both standard solutions and serum provides an excess of chlorine in the flame, thus eliminating disturbing differences between serum and standards due to other serum chlorides. A calculation of the dissociation equilibrium of $\mathrm{NaCl}$ and $\mathrm{KCl}$ at $2400^{\circ} \mathrm{K}$, based on the amounts of alkali and chlorine estimated to be present in the flame under the experimental circumstances, suggested that this excess of chlorine would repress considerably the dissociation of the alkali chlorides and consequently the emission of the alkalis. Though solutions with constant concentrations of $\mathrm{KCl}$ and $\mathrm{NaCl}$ and increasing amounts of trichloroacetic acid did give smaller deflections, this appeared to be largely due to a lower product of yield and speed of atomization. We estimate that in the flame probably no more than ro\% of the alkali will be present as the chloride, which is much less than calculated. We presume that the chlorine in the flame combines with hydrogen - which is produced in large quantities by the products of combustion of acetylene and water-to form $\mathrm{HCl}$. The dissociation potential of $\mathrm{HCl}(4.43 \mathrm{eV})$ is almost equal to that of $\mathrm{KCl}(4.40 \mathrm{eV}$; see ref. 7, p. 75). The hydrogen content of the flame was not determined.

f. In case of jaundice, the content of bile acids in the serum may be elevated, causing a decrease in surface tension. However, the highest known pathological amount, added to" a serum, gave no significant deviation.

g. Addition of $5 \%$ trichloroacetic acid has no perceptible influence on the background emission.

h. Under the conditions described, mean values found for $\mathrm{Na}$ and $\mathrm{K}$, determined

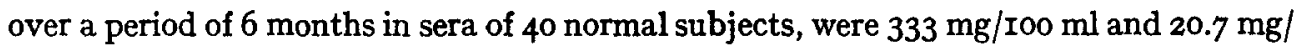
I00 $\mathrm{ml}$ respectively. This agrees satisfactorily with the values given to date.

Recoveries of known amounts of $\mathrm{K}(1.0 \mathrm{mg} / \mathrm{ro0} \mathrm{ml})$ and $\mathrm{Na}(8.0 \mathrm{mg} / \mathrm{roO} \mathrm{ml})$ added to sera of known composition, were: $97 \%$ and $96 \%$ respectively.

\section{THE PROCEDURE IN ROUTINE ANALYSIS}

\section{Preparations}

After igniting the flame 5 to ro minutes are required before a stationary state is attained and the galvanometer deflection acquires a constant value, when one solution is continually being atomized. Then distilled water is atomized and the blank is determined, corresponding with the background emission, for both the filter combinations.

\section{Readings}

First the deflections given by a number of standard solutions are measured. The occurence of possible systematical errors due to slight variations in atomization, flame emission, or sensitivity of the apparatus (see VI, c) is checked by measuring the de- 
flections for $\mathrm{Na}$ and $\mathrm{K}$ of one chief standard solution after each two readings. The composition of this solution closely resembles that of blood serum as regards the alkali content. All other deflections are expressed as percentages of the average deflections obtained with this chief standard solution. In all, five standard solutions are sufficient. They cover the whole range of possible variations in serum.

Then the solutions under investigation are measured; after each two sera the chief standard solution is read again. Deflections are always read I5 seconds after atomization is started, because at first the deflections decrease systematically. A reading takes about ro seconds, sufficient for obtaining a mean value with reasonable exclusion of accidental variations. During this time about $4 \mathrm{ml}$ of diluted serum are consumed ( $0.4 \mathrm{ml}$ blood serum).

Finally, the series of standard solutions is measured once more, to check the reproducibility. If everything is done correctly, systematical differences will not be observed.

\section{Calculations}

The background deflection is substracted from the other deflections. Then each deflection is expressed as a

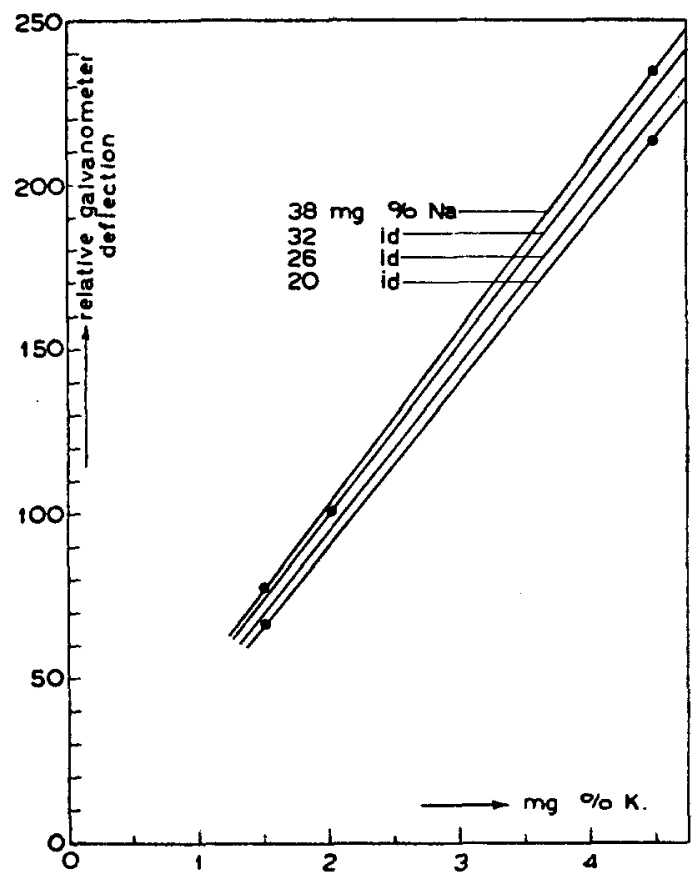

Fig. 2. Standard curve for potassium. Relative galvanometer deflections obtained with $\mathbf{K}$ filters, corrected for background emission, plotted against the $\mathrm{K}$ content of the solutions, with the $\mathrm{Na}$ content as parameter percentage of the average deflection of the chief standard solution, obtained from the foregoing and following measurement. The values obtained for the standard solutions are plotted against their $\mathrm{K}$ and $\mathrm{Na}$ contents. In the graphs for $\mathrm{K}, \mathrm{Na}$ is considered as a parameter and vice versa. For $\mathrm{K}$ a pair of straight and for $\mathrm{Na}$ a pair of curved lines is obtained (Figs. 2 and 3). For $\mathrm{Na}$ the emission seems to be about proportional to the square root of the content. The procedure of inserting other parametric lines in the graphs

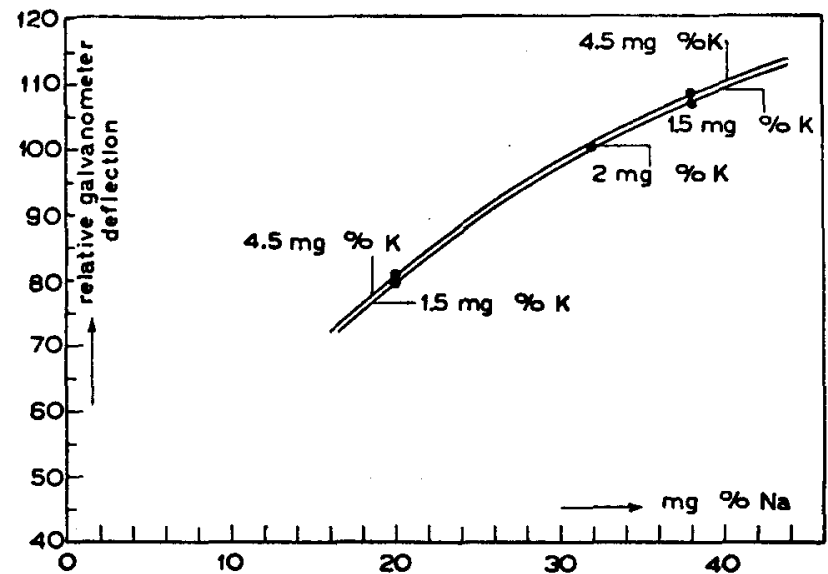

Fig. 3. Standard curve for sodium. Relative galvanometer deflections obtained with $\mathrm{Na}$ filters, corrected for background emission, plotted against the $\mathrm{Na}$ content of the solutions, with the $K$ content as parameter 
by linear interpolation proved to be permissible. The form of the curves will be discussed in $\mathrm{V}, \mathrm{I}$.

When the $\mathrm{K}$ content is not too large, the influence of $\mathrm{K}$ on the deflection given by $\mathrm{Na}$ is negligible. Therefore the $\mathrm{Na}$ content of the sera must be read first and then the $\mathrm{K}$ content, using the curve for $\mathrm{K}$ with the corresponding parameter for $\mathrm{Na}$.

TABLE V

SOME QUANTITATIVE DATA REGARDING THE DETERMINATION

\begin{tabular}{|c|c|c|}
\hline \multirow{2}{*}{$\begin{array}{l}\text { Time required for preliminary preparations concerning the apparatus } \\
\text { Time required for establishment of stationary state } \\
\text { Time required by one person for measuring } \mathrm{K} \text { and } \mathrm{Na} \text { in } 5^{\circ} \\
\text { pretreated sera } \\
\text { Composition of the chief standard solution }(\mathrm{mg} / \mathrm{1} \text {. } \mathrm{ml} \text { ) }\end{array}$} & $\begin{array}{r}2 \\
5-10\end{array}$ & ain \\
\hline & $\mathbf{K}$ & $\mathrm{Na}$ \\
\hline Composition of the other standard solutions & $\begin{array}{l}2.0 \\
1.5 \\
1.5 \\
4.5 \\
4.5\end{array}$ & $\begin{array}{l}32 \\
20 \\
38 \\
20 \\
38\end{array}$ \\
\hline $\begin{array}{l}\text { Average galvanometer deflections for a normal serum, } \\
\text { treated as described } \\
\text { Galvanometer deflections caused by background emission }\end{array}$ & $\begin{array}{l}\text { I00 } \mathrm{mm} / \mathrm{m} \\
\mathrm{K} \text { filters } \\
3.5 \mathrm{~mm} / \mathrm{m}\end{array}$ & $\begin{array}{l}130 \mathrm{~mm} / \mathrm{m} \\
\mathrm{Na} \text { filters } \\
0.5 \mathrm{~mm} / \mathrm{m}\end{array}$ \\
\hline
\end{tabular}

\section{THEORETICAI DISCUSSION OF THE STANDARD GRAPHS}

\section{The form of the curves}

The standard graph for $\mathrm{Na}$ is curved. As the detection by the phototube and the amplification are linear, this curvature must be due to partial absorption of the $\mathrm{Na}$ emission by unexcited $\mathrm{Na}$ atoms. With increasing $\mathrm{Na}$ content of the flame this selfabsorption augments. Characteristic of this so-called self-absorption is the observed proportionality of the emission to the square root of the Na content. Earlier calculations ${ }^{7}$ of the alkali content in a flame with $5 \%$ self-absorption give values far below our estimation of the $\mathrm{Na}$ content of the flame, so in our case the self-absorption must be considerable.

With low concentrations of $\mathrm{K}$ as in our case, self-absorption of $\mathrm{K}$ will be slight and its influence will be surpassed by the effect of ionization, which is of considerable importance at this high temperature and low concentration of $\mathrm{K}$. With increasing concentrations of $\mathrm{K}$ the degree of ionization will diminish; so there will be relatively more $\mathrm{K}$ atoms, causing an additional increase of the intensity of the atomic spectral line. This is indeed observed when solutions containing $\mathrm{K}$, but no $\mathrm{Na}$, are atomized (Fig. 4). The addition of Na straightens the curves, as will be explained below (Fig. 2). It is evident that the observed linearity of the standard graph for $\mathrm{K}$ in the presence of $\mathrm{Na}$ is rather fortuitous.

Owing to the excess of chlorine in the flame, the (relatively small) amount of alkali salts in the diluted serum does not influence the degree of dissociation of the alkali chlorides. Therefore, the percentage of the alkalis which are associated, and thus cannot contribute to the emission of the atomic spectral line, is independent of the alkali content of the solution. So we may expect that association will have no influence on the form of the standard curves. 


\section{Mutual influence}

There are two possible causes for the influence of one alkali on the deflection measured for the other. Firstly, owing to insufficient selectivity of the filters, a Na line

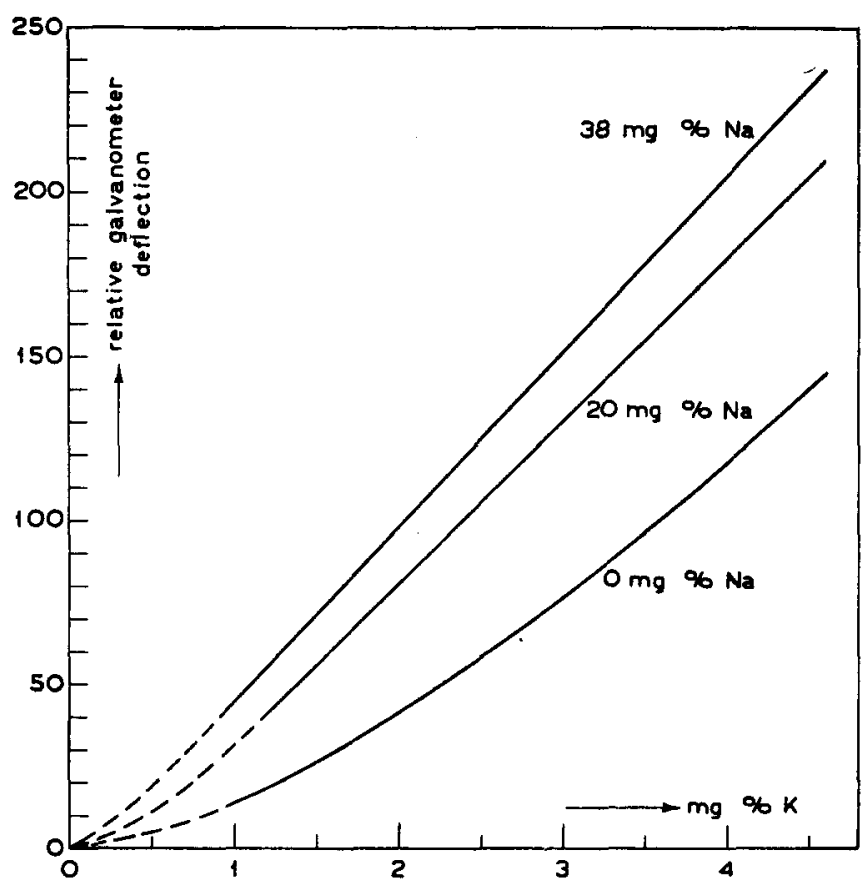

Fig. 4. Diagram for potassium. Relative galvanometer deflections obtained with $\mathrm{K}$ filters, corrected for background and "filter leakage", plotted against the $K$ content of the solutions, with the $\mathrm{Na}$ content as parameter may not be completely absorbed by the filter used for K ("filter leakage"). Secondly, a large relative excess of $\mathrm{Na}$ atoms appears to have a direct influence on the emission of $K$, which cannot be corrected by a more selective spectral apparatus (e.g. a monochromator or interference-filters).

The filter leakage can easily be demonstrated by measuring the deflection of a solution of $\mathrm{NaCl}$ with the $\mathrm{K}$ filter. For the average composition of diluted serum ( $2 \mathrm{mg} \mathrm{K}$ and $32 \mathrm{mg} \mathrm{Na}$ per roo $\mathrm{ml}$ ) the leakage augments the deflection of $\mathrm{K}$ by about $8 \%$. This leakage is not due to the yellow $\mathrm{D}$ line, as it is directly proportional to the $\mathrm{Na}$ content and it is hardly diminished by the addition of a red filter which completely absorbs the $\mathrm{D}$ line. Therefore the red $\mathrm{Na}$ doublet (8I83-95 $\AA$ ) was thought to cause the leakage. This was confirmed by making a spectrogram. This red Na doublet is difficult to separate from the red $\mathrm{K}$ doublet, but this hardly matters, for at the given composition of the serum the second, direct influence of $\mathrm{Na}$ on $\mathrm{K}$ is the most important.

As indicated recently by SMIT ${ }^{14}$, HULDT ${ }^{12}$ and VENDRIK ${ }^{7}$, the enhancement of the emission of $\mathrm{K}$ by an excess of $\mathrm{Na}$ is largely due to the repression of the ionization of $\mathrm{K}$ by electrons, produced in the flame by ionization of $\mathrm{Na}$ atoms. Thus the number of $\mathrm{K}$ atoms and consequently the atomic emission, is increased. Should this be true in our case, then a large proportion of the $K$ atoms must be ionized and there must be sufficient $\mathrm{Na}$ atoms to produce the required electrons.

Specified calculations, based on the ionization constant (derived from the equation of $\mathrm{SAHA}^{7}$ ), showed that at the given temperature and estimated content of $\mathrm{K}$ in the flame, the greater part of the $\mathbf{K}$ atoms are ionized. This is roughly confirmed by the curvature of the graph found for solutions containing only K (Fig. 4).

Further calculations indicated that in our case the excess of $\mathrm{Na}$ is sufficiently large to repress the ionization of the $\mathrm{K}$. (The ionization of the $\mathrm{Na}$ is fairly small and owing to the strong self-absorption in our experimental range the form of the curve for $\mathrm{Na}$ offers no consistent conclusions regarding the degree of ionization). 
We can thus explain three phenomena regarding the influence of $\mathrm{Na}$ on the emission of $\mathrm{K}$ :

I. The emission of $\mathbf{K}$ is enhanced (Fig. 4); when the ionization of $\mathbf{K}$ is repressed towards zero by increasing amounts of $\mathrm{Na}$ this influence reaches its limit asymptotically.

2. Owing to ionization the graph for $\mathrm{K}$ is curved, addition of $\mathrm{Na}$ straightens the curve because it reduces the ionization.

3. The influence of $\mathrm{Na}$ becomes relatively smaller at higher amounts of $\mathrm{K}$, for then $\mathrm{K}$ is less ionized (Fig. 4). This happens, for example, at higher speeds of atomization, which increase the alkali content of the flame.

To enable more detailed calculations two assumptions were made: I) an equilibrium of ionization exists in the flame, and 2) when no solution is sprayed the flame contains only a few free electrons. We now plotted the calculated increase of the emission of $\mathrm{K}$ against the ratio of $\mathrm{K}$ and $\mathrm{Na}$ content, choosing the $\mathrm{K}$ content of the flame as a parameter. In the range of concentrations under consideration a slight change in this parameter already causes a notable change in the position of the curve. In this manner a number of curves are obtained, one for each amount of $K$. Now the $K$ content of the flame may be estimated by comparing the calculated curves with the experimental data. The latter coincided with a curve possessing a $\mathrm{K}$ parameter which proved to be one fourth of the $\mathrm{K}$ content as estimated from the properties of the flame, the atomization and the content of the solutions. This result is fairly satisfactory.

The disturbance of $\mathrm{K}$ by $\mathrm{Na}$ might be expected to disappear upon adding an element with a high degree of ionization, e.g. caesium, or by using a flame of lowertem perature, in accordance with measurements performed by RIEHM ${ }^{\mathbf{1 3}}$.

Further calculation showed that in our case the interference by $\mathrm{K}$ with the emission of $\mathrm{Na}$ is much less important, as also appears from the standard curves for $\mathrm{Na}$.

Ionization also offers a quantitative explanation of both graphs given by DoMINGo ${ }^{2}$ regarding the mutual influence of $\mathrm{Na}$ and $\mathrm{K}$, assuming the temperature of the flame to be $2400^{\circ} \mathrm{K}$.

\section{THE ACCURACY OF THE DETERMINATION}

In general the accuracy of a determination is limited by the extent of the systematical errors on one hand and the magnitude of the accidental errors on the other hand. The extent of systematical errors is very difficult to estimate a priori. However, the fact that our values found for $\mathrm{Na}$ and $\mathrm{K}$ in normal blood serum agree well with the values generally assumed to be correct and that recoveries of added amounts were good, shows that in our case they do not play an important role. Accidental errors can be estimated beforehand by an accurate analysis of the various stages of the method.

The following accidental errors may arise:

a. Difference of temperature between standard and unknown solutions. An increase of temperature of $20^{\circ} \mathrm{C}$ increased the deflection for $\mathrm{K}$ by $12 \%$ and that for $\mathrm{Na}$ by $5 \%$, corresponding to a fictitious increase in content of about $12 \%$ for both elements. As mentioned previously (III, b), the speed and yield of the atomization depend upon the temperature of the solution; so the quantity of the haze introduced into the flame will also depend upon this temperature. Perhaps the temperature also has an influence on the percentage of drops that evaporate in time in the flame. In each case the magnitude of the influence will be the same for both the determinations of $\mathrm{Na}$ and $\mathrm{K}$.

References $p .523$. 
b. Difference of level between standard and unknown solutions with regard to the exit of the aspirator tube. As mentioned previously (II, 2), a difference in level will cause a difference in aspiratory speed, owing to the different hydrostatic counter pressure in the aspirator capillary. This difficulty can be largely avoided by using low, wide containers for the unknown solutions instead of test tubes and a big container with a practically constant level for the chief standard solution. A difference of $15 \mathrm{~mm}$ gave less than $\mathrm{x} \%$ difference in emission, as could also be deduced from the measured aspiratory pressure of $265 \mathrm{~cm}$ water.

c. Slow variations in the emission. These are especially observed during the first period after starting determinations, and are partly caused by a drift in the gas supplies. Serious errors are avoided by regular checking with the chief standard solution, and continuous regulation of the valves becomes superfluous. The air supply is so adjusted, that at a certain convenient and fixed acetylene supply the deflection as a function of the air supply attains a maximum. I \% change of acetylene pressure causes about $0.5 \%$ change in the deflections for $\mathrm{K}$ and $\mathrm{Na}$.

d. Rapid and irregular fluctuations in the emission. These might be due to rapid changes in gas supply, in atomization, in combustion, or to irregular movements of the flame caused by draught. The mean magnitude of the fluctuations of the deflection amounts to $1.3 \%$ for $\mathrm{K}$ and $0.5 \%$ for $\mathrm{Na}$. The error made in reading the deflection is still lower, because the deflections are observed over a certain period of time. The inaccuracy, expressed in terms of content, is about $0.8 \%$ for both $\mathrm{Na}$ and $\mathrm{K}$. Fluctuations in temperature of the flame cannot be the cause, for in that case the fluctuation of the deflection for $\mathrm{Na}$ should be $\mathrm{I} .5$ times that for $\mathrm{K}$. For the change in intensity $\Delta I$ of a resonance line, caused by a change in temperature $\Delta T$, is given by:

$$
\frac{\Delta I}{I_{0}}=\frac{k \cdot v}{k \cdot T_{0}} \cdot \frac{\Delta T}{T_{0}}
$$

in which $h$ is the Planck constant, $k$ the Boltzmann constant and $I_{0}$ the intensity at temperature $T_{0}$ of the flame.

The most important condition for a stable flame and regular combustion is probably a perfect mixing of the gases in the compartments of the burner (II, $\mathbf{r}$ ). A chimney to keep out draught was not constructed, as there were other objections against its use.

It seems that this fluctuation of emission must be due to fluctuations in the number of alkali atoms present in the part of the flame projected on the sensitive layer of the phototube; this would cause fluctuations of the same magnitude in the determination of both elements.

e. Fluctuation of the background emission of the flame. These fluctuations consist in a more or less regular noise, upon which large incidental flashes are superimposed. They are mainly caused by impurities present in the gas, the gas supply, the burner or in the air of the room. The incidental flashes are eliminated automatically by observing the deflection over a period of time. To avoid integration of these flashes a slow galvanometer should not be used. (Incidentally, a disadvantage of photographic registration of the emission is the systematical enhancement caused by the registration of these occasional fluctuations).

The fluctuations of the background emission, measured with distilled water, amount to about $0.3 \mathrm{~mm}$ for the $\mathrm{K}$ filters and $0.0 \mathrm{~mm}$ for the $\mathrm{Na}$ filters, corresponding to 0.4 and $0 \%$ respectively of the mean deflections of these elements. The influence of 
these fluctuations can be reduced by keeping the emission of alkali large in comparison to the background emission.

f. Irregular movements of the zero point of the galvanometer (with closed phototube). These are due to the inevitable noise of the amplifier ${ }^{8,9}$ and cause an uncertainty of $0.25 \%$ and $0.2 \%$ in the deflections for $\mathrm{K}$ and $\mathrm{Na}$ respectively.

g. The error in the reading of the light spot on the galvanometer scale. This amounts to about $0.2 \%$ for both $\mathrm{K}$ and $\mathrm{Na}$.

h. The non-instantaneous establishment of a constant deflection. During the first period after an atomization has been started, the deflections for both $\mathrm{K}$ and $\mathrm{Na}$ decrease considerably, until a limit value is reached asymptotically.

A stationary state in the spray and possibly also between the spray and its environment is probably not immediately established. The mean value of the variation is about $5 \%$ and $2.5 \%$ respectively of the total deflections for $\mathrm{K}$ and for $\mathrm{Na}$. It is especially large if the interval between two atomizations is longer. This considerable error can be largely avoided by reading the deflection after a certain time has elapsed after the commencement of the atomization ( $20 \mathrm{sec}$ in our case). Expressed in terms of content this effect has the same influence on both $\mathrm{K}$ and $\mathrm{Na}$, which agrees with our assumption as to its cause.

i. The composition of the standard solutions. The extent of an error in this respect can be estimated by observing the deviation of the mean position of a calibration point found with one solution, with respect to the mean position found in repeated measurements with a number of solutions of the same composition, and assumed to be correct.

j. The position of the calibration points. Even if the composition of the standard solutions is entirely correct, the position of the points used to construct the standard curves will still be subject to all accidental errors discussed above. The error in the position of these calibration points can be estimated from the dispersion found in repeated determinations of such a point with the same solution.

$k$. The drawing of the standard curves and the conversion of deflections into contents with the aid of these curves. These operations are also subject to a certain error.

1. Calculation. The calculation of the deflection as percentage of the average deflection of the chief standard solution with a slide rule has limited accuracy.

Table VI lists the mean errors expected to arise in the determination of $\mathrm{Na}$ and $\mathrm{K}$ owing to the causes discussed above.

In composing Table VI we have assumed that the composition and measurement of the chief standard solution are not subject to accidental errors. This is justified by our procedure of expressing the deflection of an unknown solution as the percentage of the average deflection of the chief standard solution obtained from the preceding and following measurements of this solution; in this mean value the effect of accidental errors is sufficiently reduced.

The expected mean "error of reproducibility", i.e. the mean deviation of the values for $\mathrm{Na}$ and $\mathrm{K}$, found if the determination is repeatedly performed in the same solution, is calculated by square summation of the errors a to $\mathrm{h}$ and 1 . We find: $\mathrm{r} .65 \%$ for $\mathrm{K}$ and $1.75 \%$ for $\mathrm{Na}$. The values found experimentally were: $\mathrm{I} .55 \%$ for $\mathrm{K}$ and $\mathrm{I.2} \%$ for $\mathrm{Na}$. This is a satisfactory result, the more so since Table VI only claims to give the relative magnitude of the possible sources of error.

References $p .523$. 
TABLE VI

ACCIDENTAL ERRORS IN THE DETERMINATION OF SODIUM AND POTASSIUM

\begin{tabular}{l|c|c}
\hline \multirow{2}{*}{ Source of error } & \multicolumn{2}{c}{ Mean error in pCt of } \\
\cline { 2 - 3 } & K content & Na content \\
\hline & & $<0.5$ \\
a. fluctuation of temperature of solutions & $<0.3$ & $<0.5$ \\
b. difference of level of solutions & 1.0 & $<0.3$ \\
c. slow variations of emission & 0.8 & 1.0 \\
d. rapid irregular variations of emission & 0.4 & 0.7 \\
e. fluctuations of background emission & 0.25 & 0.0 \\
f. fluctuations of zero point & 0.2 & 0.4 \\
g. reading of deflections & & 0.4 \\
h. non-instantaneous establishment & 0.8 & 0.9 \\
i. composition of standard solutions & 0.5 & 0.5 \\
j. position of calibration points & 1.1 & 0.9 \\
k. drawing of standard curve & 0.5 & 0.8 \\
l. calculation & 0.3 & 0.6 \\
& & \\
\hline
\end{tabular}

The mean accidental error which may be expected to occur in a determination of $\mathrm{K}$ and $\mathrm{Na}$ in diluted serum is calculated by square summation of the error of reproducibility and the errors $i, j$ and $k$. Including the supposition that the serum is measured in a single determination and the standard solution in duplicate, this error appears to be about $2 \%$ for both elements.

\section{ACKNOWIEDGEMENTS}

The authors wish to express their gratitude to Prof. J. M. W. Milatz and Dr J. A. SmIT for their interest in this work, to Miss M. DiNGs for her accurate assistance and to (another) Mr J. SMrT for his aid.

\section{SUMMARY}

I. An apparatus is described for the flame-photometric determination of alkali elements. With the exception of the burner, it is constructed from already existing standard accessories. The burner is of the type used by HEIERMAN and VENDRIK, the atomizing spray is of the type designed by BOON. The optics consist of one lens and several combinations of glass filters to select the spectral lines. For detection a $\mathrm{Cs}_{-}-\mathrm{Cs}_{\mathrm{z}} \mathrm{O}$ vacuum phototube is used. The photocurrent is measured with an a.c. galvanometer after a.c. amplification, according to MrLATz et al.

2. With this apparatus sodium and potassium can be determined in $0.5 \mathrm{ml}$ of blood serum. The accidental error of a determination is $2 \% .50$ samples can be analyzed in 3 hours, including all operations for calibration and calculation. It has also been used to determine lithium and calcium.

3. The serum to be investigated is deproteinized by tenfold dilution with a $5 \%$ solution of trichloroacetic acid and the filtrate is examined in the apparatus.

4. Mean values found from 40 determinations in sera of normal human subjects over a period of six months were: $\mathrm{Na}, 333 \mathrm{mg} / \mathrm{Ioo} \mathrm{ml} ; \mathrm{K}, 20.7 \mathrm{mg} / \mathrm{roO} \mathrm{ml}$. Recoveries of added alkalis were $96 \%$ and $97 \%$ respectively. for $\mathrm{Na}$ and $\mathrm{K}$.

5. The excess of chlorine in the flame, due to the trichloroacetic acid, prevents irregularities which might otherwise be caused by a shifting of the dissociation equilibria for $\mathrm{KCl}$ and $\mathrm{NaCl}$. The situation is somewhat complicated owing to the presence of hydrogen in the flame.

6. Several organic solvents enhance the atomization, giving at most an eightfold increase of the galvanometer deflections for $2 \mathrm{mg} \mathrm{K}$ per roo $\mathrm{ml}$ solution.

7. The form of the standard curves is discussed. Self-absorption accounts for the curvature of References p. 523. 
the $\mathrm{Na}$ graph; the form of the $\mathrm{K}$ graph is determined by the ionization of the $\mathrm{K}$ under the prevailing circumstances.

8. The presence of an excess of $\mathrm{Na}$ has a marked influence on the determination of $\mathrm{K}$. This is theoretically and experimentally shown to be mainly caused by the repression of the ionization of $\mathrm{K}$ by electrons originating from the $\mathrm{Na}$. In practice a simple graphical correction removes this difficulty.

9. The error of $2 \%$ in the determination is quantitatively accounted for by a critical evaluation of the separate accidental errors involved in the procedure.

\section{RÉSUMÉ}

r. Nous décrivons un appareil pour la déterndination flamme-photométrique des éléments alcalins. A l'exception du brâleur cet appareil se compose d'accessoires standard. Le braleur est du type utilisé par HeIERMAN et VENDRIK, l'atomiseur du type dessiné par Boon. Le système optique se compose d'une lentille et de plusieurs combinaisons de filtres en verre pour la sélection des lignes spectrales. La détection se fait à l'aide d'un photo-tube à vide, à $\mathrm{Cs}-\mathrm{Cs}_{2} \mathrm{O}$. Le courant alternatif engendré est amplifié et mesuré à l'aide d'un galvanomètre pour courant alternatif, suivant MiLATz et al.

2. A l'aide de cet appareil on peut déterminer le sodium et le potassium dans $0.5 \mathrm{ml}$ de sérum. L'erreur accidentelle d'une détermination est de $2 \%$. 50 Prises peuvent être analysées en trois heures, toutes opérations de calibrage et de calcul comprises. Le lithium et le calcium ont également été déterminés à l'aide de cet appareil.

3. On élimine les protéines du sérum à analyser en le diluant dix fois par une solution d'acide trichloracétique à $5 \%$, puis on examine le filtrat obtenu dans notre appareil.

4. Les valeurs moyennes trouvées en $4^{0}$ déterminations dans du sérum de personnes normales au cours d'une période de six mois sont: $\mathrm{Na}, 333 \mathrm{mg} / \mathrm{r} 00 \mathrm{ml} ; \mathrm{K}, 20.7 \mathrm{mg} / 100 \mathrm{ml}$. On retrouve respectivement 96 et $97 \%$ du Na et du $\mathrm{K}$ ajoutés.

5. L'excès de chlore dans la flamme dâ à l'acide trichloracétique empêche les irrégularités qui pourraient être causées par déplacement des équilibres de dissociation de $\mathrm{KCl}$ et $\mathrm{NaCl}$. La situation est compliquée quelque peu par la présence d'hydrogene dans la flamme.

6. Plusieurs solvents organiques stimulent l'atomisation; la déviation du galvanomètre peut ainsi être augmentée 8 fois au plus, pour $2 \mathrm{mg}$ de $\mathrm{K}$ par $100 \mathrm{ml}$ de solution.

7. Nous avons discuté l'allure des courbes d'étalonage. La courbure du graphique se rapportant au sodium s'explique par autoabsorption, celle du graphique se rapportant au potassium par l'ionisation de ce dernier sous les circonstances régnantes.

8. La présence d'un excès de $\mathrm{Na}$ a une influence marquée sur la détermination du $\mathrm{K}$. Nous avons montré théoriquement et expérimentalement que ceci est surtout dû au fait que des électrons provenant du $\mathrm{Na}$ répriment l'ionisation du K. En pratique une simple correction graphique permet d'éliminer cet inconvénient.

9. L'on peut expliquer quantitativement l'erreur de $2 \%$ par détermination, en estimant critiquement les erreurs accidentelles individuelles que comporte la méthode.

\section{ZUSAMMENFASSUNG}

r. Ein Apparat zur flammenphotometrischen Bestimmung der Alkalielemente wird beschrieben. Mit Ausnahme des Brenners ist dieser Apparat aus bereits bestehenden Standard-Bestandteilen gebaut. Der Brenner ist vom Typus Hemerman-Vendrik, der Zerstäuber vom Typus Boon. Die Optik besteht aus einer Linse und mehreren Kombinationen von Glasfiltern zum Selektieren der Spektrallinien. Zum Nachweis wird eine $\mathrm{Cs}_{s}-\mathrm{Cs}_{9} \mathrm{O}$ Vakuum-Photoröhre gebraucht. Der erzeugte Strom wird mit Hilfe eines Wechselstrom-Galvanometers nach Wechselstromverstärkung, nach MrLATZ et al. gemessen.

2. Mit Hilfe dieses Apparates konnen Natrium und Kalium in $0.5 \mathrm{ml}$ Blutserum bestimmt werden. Der Zufälligkeitsfehler für eine Bestimmung beträgt $2 \%$. 50 Proben können, alle Kalibrierund Rechnungsoperationen inbegriffen, in 3 Stunden analysiert werden. Lithium und Calcium wurden auch bestimmt.

3. Das zu untersuchende Serum wird durch zehnfache Verdünnung mit $5 \%$-iger Trichloressigsäure enteiweisst und das Filtrat im Apparat untersucht.

4. Die gefundenen mittleren Werte von $4^{\circ}$ Bestimmungen in Serum von normalen Menschen in einer Zeitspanne von 6 Monaten betrugen: $\mathrm{Na}, 333 \mathrm{mg} / \mathrm{roo} \mathrm{ml} ; \mathrm{K}, 20.7 \mathrm{mg} / \mathrm{roo} \mathrm{ml} .96 \%$ der zugefügten Natrium-Menge und $97 \%$ des Kaliums wurden zurückgewonnen.

5. Der, durch die Trichloressigsäure verursachte, Chlorüberschuss in der Flamme verhindert das Auftreten von Unregelmässigkeiten, welche sonst durch Verschiebung des Dissoziationsgleichge-

References p. 523 . 
wichtes von $\mathrm{KCl}$ und $\mathrm{NaCl}$ entstehen könnten. Die Vorgänge werden durch das Vorhandensein von Wasserstoff in der Flamme etwas kompliziert.

6. Mehrere organische Lösungsmittel verstärken die Zerstäubung; der Galvanometerausschlag kann so maximal, für $2 \mathrm{mg} \mathrm{K}$ pro $100 \mathrm{ml}$ Lösung, auf das 8-fache erhöht werden.

7. Die Form der Standardkurven wird erörtert. Selbstabsorption erklärt die Krümmung der Na-Kurve; die Form der K-Kurve wird durch die Ionisation des Kaliums unter den herrschenden Bedingungen bestimmt.

8. Ein Uberschuss an Natrium beeinflusst die Bestimmung des Kaliums bedeutend. Es wird theoretisch und experimentell gezeigt, dass dies hauptsächlich auf Hemmung der Ionisation des Kaliums durch Elektronen, die vom Natrium herrühren, zurückzuführen ist. In der Praxis kann diese Schwierigkeit durch eine einfache graphische Korrektur überwunden werden.

9. Der Fehler von $2 \%$ bei einer Bestimmung wird durch eine kritische Schätzung der einzelnen Zufälligkeitsfehler, welche der Methode anhaften, quantitativ gedeutet.

\section{REFERENCES}

1 A. C. Schutrelen, Thesis, Utrecht (1940).

2 W. R. Domingo and W. KLYNe, Biochem. J., 45 (1949) 400.

3 S. D. Boon, Thesis, Amsterdam (1945).

A. F. Willebrands, Chem. Weekblad, 45 (1945) 344.

${ }^{5}$ F. WAIBeI, Z. techn. Phys., I 5 (1934) 454.

- J. H. HeIERMan, Thesis, Utrecht (1937);

E. F. M. van der Held and J. H. Heierman, Physica, 3 (1936) 3 I.

7 A. J. H. VendRIK, Thesis, Utrecht (1949).

8 J. M. W. Milatz, Thesis, Utrecht (1937).

- J. M. W. Milatz and N. Blofmbergen, Physica, i I (1946) 449.

10 J. M. W. Milatz, P. M. Endt, C. Th. J. AlkeMade, AND J. Th. Olink, Physica, $\mathrm{I}_{4}$ (1948) 260.

11 H. Putzman, Spectrochimica Acta, I (1939) 408.

12 L. HuLdT, Thesis, Uppsala (I948).

13 H. Rien м, $Z$. A nal. Chem., I28 (1948) 249.

14 J. A. Smit and A. J. H. Vendrik, Physica, 14 (I948) 505.

Received July 26 th, r950 